\title{
LA Grade D
}

National Cancer Institute

\section{Source}

National Cancer Institute. LA Grade D. NCI Thesaurus. Code C62427.

Mucosal breaks which involve at least $75 \%$ of the esophageal circumference. 